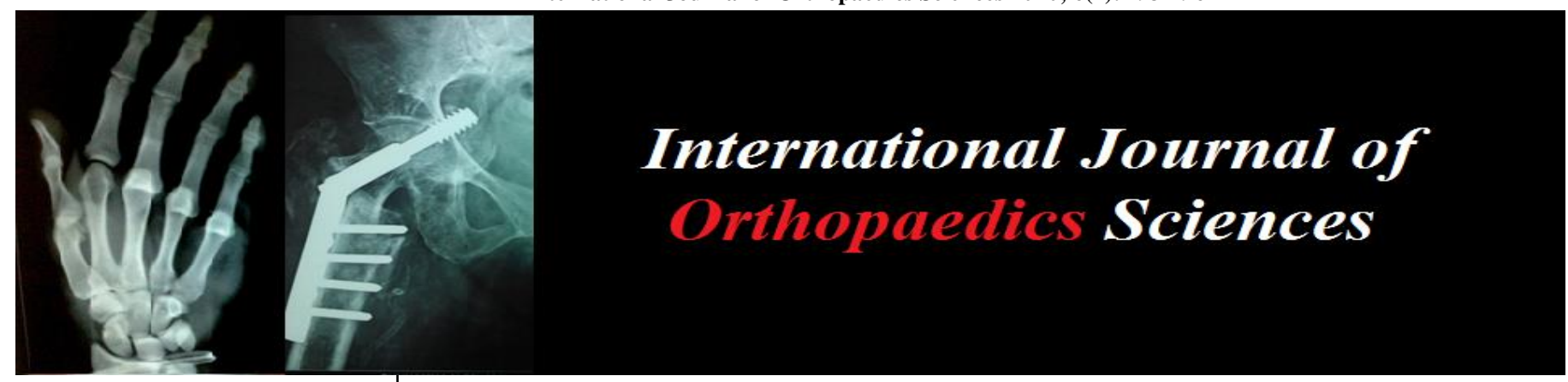

E-ISSN: 2395-1958

P-ISSN: 2706-6630

IJOS 2020; 6(2): 493-496

(C) 2020 IJOS

www.orthopaper.com

Received: 18-02-2020

Accepted: 20-03-2020

Nishat Setia

Fellow Arthroplasty, Sunshine

Hospital, Hyderabad,

Telangana, India

Kanish Kinra

Senior Resident, Orthopaedics, ESIC Model Hospital, Ludhiana,

Punjab, India

Divya Bansal

Consultant Radiology, Vijaya

Diagnostics, Hyderabad,

Telangana, India

Neha Setia

MBBS Student, Shandong First

Medical University, China

Corresponding Author:

Kanish Kinra

Senior Resident, Orthopaedics,

ESIC Model Hospital, Ludhiana,

Punjab, India

\section{Spinal Tuberculosis: Its clinical presentation, management and outcome - A retrospective study}

\author{
Nishat Setia, Kanish Kinra, Divya Bansal and Neha Setia
}

DOI: https://doi.org/10.22271/ortho.2020.v6.i2h.2088

\begin{abstract}
Tuberculosis (TB) of the spine (Pott's disease) is the most common skeletal form of TB infection. In India, Pott's disease remains a serious problem, causing paraplegia. It should be considered when patients present with neurological findings suggesting of cord compression and spinal deformity, delay in establishing diagnosis and management cause spinal cord compression causing neurological impairment and kyphotic spinal deformity. In this retrospective study, we report our experience with the management of 20 patients with Pott's disease in the past 2 years. The mean patient age was 40 years. Nine (45\%) were men, nine (45\%) were women and Two (10\%) children, both female. Nineteen $(95 \%)$ had a positive tuberculin skin test, and Six $(30 \%)$ had pulmonary tuberculosis. Symptoms consisted of pain, motor weakness, fever, sensory complaints, and flank mass in order of decreasing frequency. Two patients were neurologically intact; the remainder had motor deficits of variable severity. Isolated cervical spine was involved in $2(10 \%)$ patients, isolated dorsal spine was involved in $7(35 \%)$ patients, isolated lumbar spine was involved in $5(25 \%)$ patients, the thoraco-lumbar spine was involved in $5(25 \%)$ patients and the lumbo-sacral spine was involved in $1(5 \%)$ patient. Spinal deformity was present in 8 patients, spinal epidural compression was present in 13 patients, and a paraspinal mass was present in 16 patients. Operative indications included motor deficits, non-diagnostic computer tomographic-guided needle biopsy, and non-compliance with, or lack of response to medical therapy. Eight patients underwent operation, seven had antero-lateral decompression done with paraspinal abscess drainage \& one had laminectomy assisted decompression. Patients have been monitored periodically and almost all have neurologically improved or normalized without residual infection. In the present study, it was concluded that early initiation of Anti Tubercular Therapy along with early operative decompression in selected patients, when indicated, minimizes neurological deterioration and spinal deformity, results in early mobilization and excellent neurological outcome of the patients.
\end{abstract}

Keywords: Spinal tuberculosis, paraplegia, anti-tubercular therapy, decompression

\section{Introduction}

Spinal tuberculosis was known in ancient Egypt. It was described by Hippocrates, and in 1779, Percivall Pott published the first modern description of spinal deformity and paraplegia resulting from spinal TB1,2,3. The World Health Organization estimates that there are about 30 million patients with tuberculosis in the world today. Among them, about 3\% have musculoskeletal involvement, and the spine is affected in half of these cases. 1 Although spinal involvement occurs in less than $1 \%$ of patients with TB. 3,4 It is both the most common and the most dangerous form of TB infection. Even today, TB of the spine (Pott's disease) is still a life-threatening condition in spite of all the advances in diagnostic procedures, surgical techniques, and effective tuberculostatic drugs. Delay in establishing the diagnosis and surgically relieving the spinal cord compression can lead to the progression of neurological deficit and spinal deformity, thereby diminishing the likelihood of recovery.

Materials and methods: The study was conducted over a period of two calendar year from April 2017 to March 2019 at Department of Orthopaedics, North DMC Medical College \& Hindu Rao Hospital. We have been treating our patients mostly with anti-tuberculous chemotherapy, rest and spinal braces. Hospitalisation has been restricted to the paraplegics who were unable to walk, or to patients who required evacuation of abscesses or debridement of vertebral lesions. In all patients ATT consisting of daily dose of Isoniazid, Ethambutol, 
Rifampicin \& Pyrazinamide for an intensive phase of 2 months followed by Isoniazid, Rifampicin and Etahmbutol for a continuation phase of 7-10 months was started from the day of diagnosis. Surgical intervention was opted when patient had progressive deterioration of neurological symptoms or if the size of paravertebral abcess kept on increasing inspite of anti-tubercular therapy. Operative treatments included Antero-lateral decompression in most of the cases and laminectomy assisted decompression was also performed in select few cases of paraplegia. Patients were called for checkup at every three-month interval, radiographs and erythrocyte sedimentation rates were done. All patients were evaluated by MRI after 9-12 months of ATT to decide on continuation of ATT on patient to patient basis. Gradual mobilization of the patient is encouraged with the help of spinal braces after six to nine months of bed rest, depending upon the progress of healing.

Neurological examination was performed at each follow-up visit with use of the classification system of Frankel et al. ${ }^{[5]}$

Table I: Frankel classification of spinal injury ${ }^{[5]}$.

\begin{tabular}{|c|c|}
\hline Grade & Neurological status \\
\hline A & Complete neurological deficit with no sensory or motor sparing distal to the spinal lesion \\
\hline B & Sparing of some sensation but no motor function distal to the spinal lesion. \\
\hline C & Sparing of sensation but no useful motor function distal to the spinal lesion \\
\hline D & Sparing of sensation and useful motor function distal to the spinal lesion. \\
\hline E & Normal neurology. \\
\hline
\end{tabular}

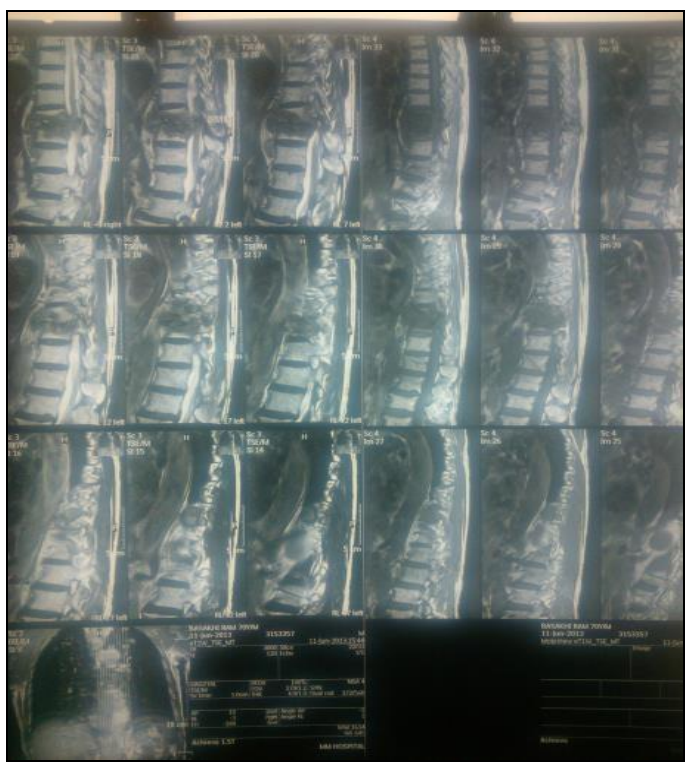

Fig 1

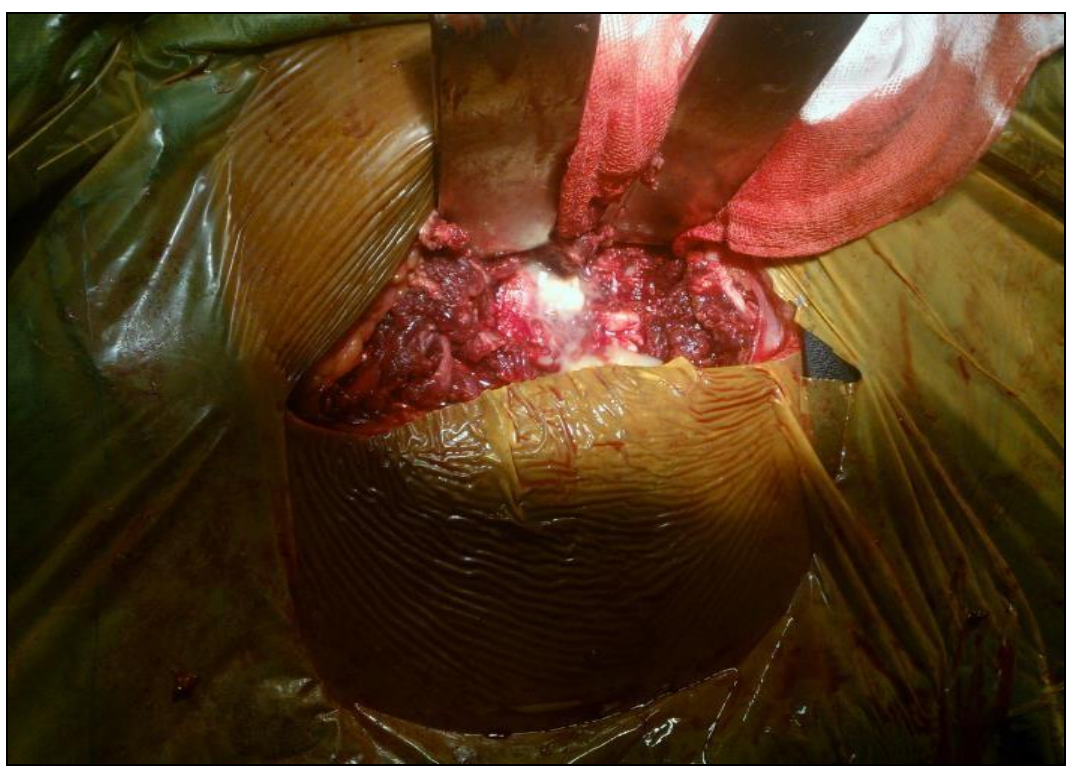

Fig 2

Table II:

\begin{tabular}{|c|c|c|c|c|c|c|c|c|}
\hline \multirow[b]{2}{*}{ Case } & \multirow[b]{2}{*}{$\begin{array}{l}\text { Involved } \\
\text { levels }\end{array}$} & \multirow{2}{*}{$\begin{array}{c}\text { No of } \\
\text { involved } \\
\text { levels } \\
\end{array}$} & \multirow{2}{*}{$\begin{array}{l}\text { Treatment } \\
\text { given }\end{array}$} & \multicolumn{2}{|c|}{ Neurological Status } & \multirow{2}{*}{$\begin{array}{c}\text { Duration of } \\
\text { neurological } \\
\text { symptoms (weeks) }\end{array}$} & \multirow{2}{*}{$\begin{array}{c}\text { Time for neurological } \\
\text { recovery in surgical } \\
\text { cases (weeks) }\end{array}$} & \multirow[b]{2}{*}{ MRI Findings } \\
\hline & & & & $\begin{array}{c}\text { Before } \\
\text { treatment }\end{array}$ & $\begin{array}{c}\text { After } \\
\text { treatment }\end{array}$ & & & \\
\hline 1 & Thoracic & 2 & ATT & $\mathrm{D}$ & $\mathrm{E}$ & 0 & & $\begin{array}{c}\text { Infective Spondylodiscitis, } \\
\text { cord edema, extradural } \\
\text { granulation tissue }\end{array}$ \\
\hline 2 & $\begin{array}{l}\text { Thoraco- } \\
\text { Lumbar }\end{array}$ & 2 & ATT & $\mathrm{E}$ & $\mathrm{E}$ & 2 & & Infective Spondylodiscitis \\
\hline 3 & Thoracic & 3 & $\mathrm{ATT}+\mathrm{SD}$ & $\mathrm{B}$ & $\mathrm{D}$ & 2 & 12 & $\begin{array}{c}\text { Paravertebral } \\
\text { Abscess,Fistula } \\
\end{array}$ \\
\hline 4 & Lumbar & 3 & ATT & $\mathrm{D}$ & $\mathrm{E}$ & 3 & & $\begin{array}{c}\text { Infective Spondylodiscitis } \\
\text { with cord edema }\end{array}$ \\
\hline 5 & Lumbar & 2 & ATT & $\mathrm{D}$ & $\mathrm{E}$ & 2 & & $\begin{array}{l}\text { Infective Spondylodiscitis } \\
\text { with cord edema }\end{array}$ \\
\hline 6 & Thoracic & 2 & $\mathrm{ATT}+\mathrm{SD}$ & $\mathrm{C}$ & $\mathrm{C}$ & 4 & $\begin{array}{c}\text { No } \\
\text { Recovery }\end{array}$ & Paravertebral Abscess \\
\hline 7 & $\begin{array}{l}\text { Thoraco- } \\
\text { Lumbar }\end{array}$ & 2 & ATT & $\mathrm{D}$ & $\mathrm{E}$ & 1 & & $\begin{array}{l}\text { Infective Spondylodiscitis } \\
\text { with cord edema }\end{array}$ \\
\hline 8 & Thoracic & 3 & $\mathrm{ATT}+\mathrm{SD}$ & $\mathrm{B}$ & $\mathrm{C}$ & 6 & 10 & $\begin{array}{c}\text { Paravertebral Abscess with } \\
\text { unilateral Psoas Abscess }\end{array}$ \\
\hline 9 & Cervical & 2 & ATT & $\mathrm{D}$ & $E$ & 2 & & Infective Spondylodiscitis \\
\hline 10 & $\begin{array}{l}\text { Thoraco- } \\
\text { Lumbar }\end{array}$ & 3 & $\mathrm{ATT}+\mathrm{SD}$ & $\mathrm{D}$ & $\mathrm{E}$ & 1 & 2 & Paravertebral Abscess \\
\hline 11 & $\begin{array}{l}\text { Lumbo- } \\
\text { Sacral }\end{array}$ & 3 & ATT & $\mathrm{D}$ & $\mathrm{E}$ & 2 & & $\begin{array}{c}\text { Infective Spondylodiscitis } \\
\text { with cord edema }\end{array}$ \\
\hline 12 & Thoracic & 2 & $\mathrm{ATT}+\mathrm{SD}$ & $\mathrm{C}$ & $\mathrm{D}$ & 3 & 6 & Paravertebral Abscess \\
\hline 13 & $\begin{array}{l}\text { Thoraco- } \\
\text { Lumbar }\end{array}$ & 3 & ATT & $\mathrm{D}$ & $\mathrm{E}$ & 2 & & $\begin{array}{l}\text { Infective Spondylodiscitis } \\
\text { with cord edema }\end{array}$ \\
\hline 14 & Lumbar & 2 & ATT & $\mathrm{E}$ & $\mathrm{E}$ & 2 & & Infective Spondylodiscitis \\
\hline
\end{tabular}




\begin{tabular}{|c|c|c|c|c|c|c|c|c|}
\hline 15 & Thoracic & 1 & ATT & D & E & 1 & $\begin{array}{c}\text { Infective } \\
\text { Spondylodiscitisextradural } \\
\text { granulation tissue }\end{array}$ \\
\hline 16 & Cervical & 2 & ATT & D & E & 2 & $\begin{array}{c}\text { Partial collapse of vertebral } \\
\text { body }\end{array}$ \\
\hline 17 & Thoracic & 1 & ATT+SD & B & D & 4 & 1 & 1 \\
\hline 18 & $\begin{array}{c}\text { Thoraco- } \\
\text { Lumbar }\end{array}$ & 2 & ATT+SD & D & E & 1 & $\begin{array}{c}\text { Paravertebral Abscess with } \\
\text { bilateral Psoas Abscess }\end{array}$ \\
\hline 19 & Lumbar & 2 & ATT & D & E & 2 & $\begin{array}{c}\text { Infective Spondylodiscitis } \\
\text { with small extradural } \\
\text { granulation tissue }\end{array}$ \\
\hline 20 & Lumbar & 2 & ATT+SD & C & D & 5 & 10 & Epidural Abscess \\
\hline
\end{tabular}

\section{Results}

Table III:

\begin{tabular}{|c|c|c|c|c|c|c|c|}
\hline Results & cervical & Isolated thoracic & Thoraco- lumbar & Isolated lumbar & Lumbo- sacral & Total cases & $\%$ \\
\hline Complete Recovery & 2 & 3 & 5 & 4 & 1 & 15 & 75 \\
\hline Partial Recovery & - & 3 & - & 1 & - & 4 & 20 \\
\hline No recovery & - & 1 & - & - & - & 1 & 5 \\
\hline Deterioration & - & - & - & - & - & - & - \\
\hline
\end{tabular}

The results are shown in table III. All 20 patients were given Anti-Tubercular Therapy, of which 8 patients also underwent surgical decompression (Antero-lateral decompression in 7 patients and laminectomy assisted decompression in 1 patient). Periodic follow-up evaluation showed two patients with cervical spine TB had complete neurological recovery. Out of seven patients with isolated thoracic spine TB, three recovered completely, three had partial recovery with reasonable alleviation of symptoms and one patient showed no sign of recovery. Five patients with thoraco-lumbar TB recovered completely. Out of five patients with isolated lumbar spine involvement, four recovered completely and one managed partial improvement. One patient with lumbo-sacral disease had complete neurological recovery with complete resolution of presenting spinal symptoms.

\section{Discussion}

Unfortunately, even today TB still remains a source of socioeconomic and follow-up problems in many developing nations, despite the availability of effective chemotherapeutical agents and World Health Organization (WHO) efforts to improve public health.6 Tuberculosis infection typically affects the vertebral body itself in the lower thoracic and upper lumbar regions, and the posterior elements are rarely affected ${ }^{[4,7,8]}$. Although, in general, TB has become less widespread globally, it is still responsible for $25 \%$ of cases of spinal extradural abscess and is usually associated with vertebral osteomyelitis ${ }^{[4,8]}$. Early findings may not be visible on plain radiography for up to 8 weeks. 9 Hence, CT and MRI have become the radiological modalities of choice in the diagnosis of Pott's disease as a high sensitivity and specificity in the early diagnosis of spinal TB can be achieved using both CT and MRI scans.1,10 MRI scanning is extremely useful for assisting in the diagnosis and surgical planning, but is by no means diagnostic. Confusion, particularly with metastatic malignancy, is possible and a tissue diagnoses is still essential $[11,12]$. We recommend that the entire spine should be X-rayed in TB spine patients, and preferably a whole spine sagittal MRI performed.CT-guided fine-needle aspiration is a useful method for confirming histopathological and microbiological studies as accurate diagnosis can only be obtained by the isolation of $M$. tuberculosis in the materials taken by fnac or during surgical intervention ${ }^{[10,13]}$. Once identified, the lesions should be managed based on their merit.
The mean age in our study was 40 years, which is same as in various other studies (range, 35-53 years) ${ }^{[1,10,14,15]}$. Older age is a factor related to an unfavorable outcome, which confirms the findings reported in previous studies.15 The most common presenting symptoms of spinal TB in our study were back pain, neurological deficits and fever. Neurological involvement in spinal TB has been reported in $23-76 \%$ of patients, with differences in severity $[1,10,14,15]$. Longer duration of symptoms prior to diagnosis may contribute to progression of the vertebral lesion and often results in the appearance of neurological deficits. 1

Chemotherapy alone is adequate in a majority of patients belonging to Frankel grade E. Patients with grade D may also get adequate relief from chemotherapy alone, but some patients deteriorate while on treatment and require surgery. Tuli ${ }^{[16,17]}$ reported a series where 118 of 200 patients who were started on chemotherapy subsequently required surgery but this study did not indicate the levels of neurological deficit. In 1985, Lifeso14 reported that chemotherapy alone produced good results, even in patients with neurological problems, but the majority of his patients were Frankel grades $\mathrm{C}, \mathrm{D}$ and E. Only 16 patients were classified as grade A or B. It should be noted that there is a group of patients with spinal tuberculosis who can present with minimal neurological symptoms in the presence of significant epidural compression. Sooner or later, however, these patients will present with neurological signs, even when on adequate chemotherapy. It is therefore essential to carefully assess the actual degree of spinal cord involvement whenever there is evidence of even minimal neurological compression. If cord compression is found to be significant, anterior decompression is indicated, even if the neurological signs are minimal ${ }^{[18]}$. This will prevent patients returning later with further deterioration of neurological symptoms.

\section{The indications for surgery are}

1) neurological deficit caused by spinal cord compression;

2) spinal instability caused by vertebral collapse, vertebral destruction, or a kyphotic angle of $>30^{\circ}$ (or a progressive angle);

3) no response to, or failure of, anti-TB therapy

4) large paraspinal abscess; and

5) non-diagnostic biopsy ${ }^{[19,20]}$.

A Cochrane review of randomized controlled trials regarding 
the use of routine surgery in addition to chemotherapy for spinal TB concluded that there was no significant benefit from the routine use of surgery ${ }^{[21]}$. However, in our study, univariate analysis suggests a trend towards favorable outcomes after combined medical and surgical treatment. The proportion of patients who received surgery varies from $20.0 \%$ to $70.5 \%[1,14,15]$. A relatively higher surgical rate $(40 \%)$ was observe in our study, possibly due to the fact that there was a high percentage of patients with a neurological deficit, as 6 patients (30\%) belonged to Frankel grade B/C and 12 patients were Frankel grade D (60\%) out of which 2 patients on chemotherapy underwent surgery due to deterioration of neurological status. In India, unfortunately most of the patients with Pott's disease have large abscesses, neurological involvement, and multisegmental involvement when admitted. In these patients, undoubtedly the best results can be obtained with a combined approach.

In our series, in the patients having severe neurological deficit, we carried out aggressive surgery. Of the 8 patients operated, 2 had complete neurological recovery, 5 were noted to have only partial recovery at the time of reporting. There was no improvement in 1 of our patients with lesions in the thoracic spine.

Finally, the importance of long-term anti-TB medication after discharge should be kept in mind, as some patients may erroneously discontinue to take the recommended chemotherapeutical agents due to early improvement in their clinical status. Hence, regular follow-ups with strict vigilance on doctor's part can help overcome this obstacle.

\section{Conclusion}

Therefore, we think that Pott's disease should be treated by chemotherapy combined with surgery because of the advanced stage of the disease in most patients, as commonly seen in our country. It was concluded that:

1. India being one of the nations where $\mathrm{TB}$ is still encountered as an important cause of paraplegia, it should be suspected when patients present with neurological findings suggesting cord compression or back pain. Early diagnosis and treatment is related to a more favorable outcome.

2. The neurological involvement due to Pott's disease is relatively benign if urgent decompression is performed at the onset of disease if indicated, along with a full disciplined course of chemotherapy in all patients.

\section{References}

1. Colmenero JD, Jimenez-Mejias ME, Reguera JM, Palomino-Nicas J, Ruiz-Mesa JD, Marquez-Rivas J et al. Tuberculous vertebral osteomyelitis in the new millennium: still a diagnostic and therapeutic challenge. Eur J Clin Microbiol Infect Dis. 2004; 23:477-83.

2. Tuli SM. Tuberculosis of the spine: a historical review. Clin Orthop Relat Res. 2007; 460:29-38.

3. Açıkgöz B, Özcan OE, Belen D, Erbengi, A, Özgen T. Surgery for progressive Pott's paraplegia (tuberculous paraplegia). Paraplegia. 1991; 29:537-541.

4. Azzam NI, Tammawy M. Tuberculous spondylitis in adults: diagnosis and treatment. Br J Neurosurg. 1988; 2:85-91.

5. Frankel HL, Hancock DO, Hyslop G, Melzak J, Michaelis LS, Ungar GH et al. The value of postural reduction in the initial management of closed injuries of the spine with paraplegia and tetraplegia. Part I. Paraplegia. 1969; 7:179-192.
6. Medical Research Council Working Party On Tuberculosis of the Spine A controlled trial of anterior spinal fusion and debridement in the surgical management of tuberculosis of spine in patients on standard chemotherapy: a study in two centers in South Africa. Seventh Report. Tubercle. 1978; 59:79-105.

7. Arthornthurasook A, Chongpieboonpatana A. Spinal tuberculosis with posterior element involvement. Spine. 1990; 15:191-194.

8. Rahman N. Atypical forms of tuberculosis. J Bone Joint Surg Br. 1980; 62:162-169.

9. Sharif HS, Morgan JL, al Shahed MS, al Thagafi MY. Role of CT and MR imaging in the management of tuberculous spondylitis. Radiol Clin North Am. 1995; 33:787-804.

10. Francis IM, Das DK, Luthra UK, Sheikh Z, Sheikh M, Bashir M. Value of radiologically guided fine needle aspiration cytology (FNAC) in the diagnosis of spinal tuberculosis: a study of 29 cases. Cytopathology. 1999; 10:390-401.

11. Ahmadi J, Bajaj A, Destian S, Segall HD, Chi-Shing Z. Spinal tuberculosis: atypical observations at MR imaging. Radiology. 1993; 189(2):489-493.

12. Griffith JF et al. Imaging of musculoskeletal tuberculosis: a new look at an old disease. Clin Orthop Relat Res. 2002; (398):32-39.

13. Mondal A. Cytological diagnosis of vertebral tuberculosis with fine-needle aspiration biopsy. J Bone Joint Surg Am. 1994; 76:181-4.

14. Lifeso RM, Weaver P, Harder EH. Tuberculous spondylitis in adults. J Bone Joint Surg Am. 1985; 67:1405-13.

15. Pertuiset E, Beaudreuil J, Liote F, Horusitzky A, Kemiche F, Richette $\mathrm{P}$ et al. Spinal tuberculosis in adults. A study of 103 cases in a developed country, 1980-1994. Medicine (Baltimore). 1999; 78:309-20.

16. Tuli SM. Results of treatment of spinal tuberculosis by middle path regime. 7 Bone joint Surg 1975; 57B: 13-23.

17. Tuli SM. Tuberculosis of the Spine. New Delhi: Atmaram, 1975.

18. Hodgson AR, Stock FE. Anterior spinal fusion. J Bone joint Surg. 1960; 42A:295-309.

19. Moon MS. Tuberculosis of the spine. Controversies and a new challenge. Spine. 1997; 22:1791-7.

20. Nussbaum ES, Rockswold GL, Bergman TA, Erickson DL, Seljeskog EL. Spinal tuberculosis: a diagnostic and management challenge. J Neurosurg. 1995; 83:243-7.

21. Jutte PC, Van Loenhout-Rooyackers JH. Routine surgery in addition to chemotherapy for treating spinal tuberculosis. Cochrane Database Syst Rev. 2006; CD004532. 